\title{
Marketing Communication of Multinational Retail Chain during Global Pandemic in the Online Environment
}

\author{
Daniela Kollárová ${ }^{1, *}$, and Magdaléna Ungerová ${ }^{2}$ \\ ${ }^{1}$ UCM, Department of Marketing Communication, 91701 Trnava, Slovakia \\ ${ }^{2}$ UCM, Department of Linguistic Communication, 91701 Trnava, Slovakia
}

\begin{abstract}
.
Research background: The epidemic that has hit us on a global scale has had a negative impact not only on the work-related, social, and personal lives of each individual or household, but also on the economies of different countries and, last but not least, on decision-making of companies. One of the areas in which we noticed clearly the influence of the pandemic was the communication of retail chains with their customers: e.g., Kaufland stopped the unaddressed distribution of its promotional leaflets and tried to redirect the interest of customers to the digital (online) environment. With our paper we respond to this measure. The object of our research is the posts of the multinational retail chain Kaufland published on its Facebook account, intended for customers on the Slovak and German markets, during the period when a state of emergency was imposed in Slovakia.

Purpose of the article: The main purpose of the content analysis is to find out the topics of the online contents of the retail chain Kaufland in Slovakia in communication with customers during an emergency state on its Facebook pages and compare them with the topics of articles posted during the observed period on the company's Facebook pages in Germany. Methods: Digital contents are divided into contributions related and not related to the pandemic. As Germany did not impose general restrictions, we found out that in comparison with Slovakia, some themes related to the health protection or social responsibility did not appear on the Facebook pages of Kaufland in Germany.

Findings \& Value added: Conversely, Kaufland Slovakia did not assure customers that stores were regularly supplied and customers did not have to fall into purchasing hysteria, did not encourage customers to move to digital (online) environment and also did not publish job offers (for temporary work) in its shops or by its suppliers. The number of pandemicrelated posts has been declining over the examined period.
\end{abstract}

Keywords: marketing communication; retail; globalization; pandemic

JEL Classification: $M 31 ; L 81 ; D 83$

*Corresponding author: daniela.kollarova@ucm.sk 


\section{Introduction}

The issue of offline marketing communication is given constant attention, but towards online and digital communications, consideration has intensified only in the last decade. Many authors from academic and professional circles comment on the given areas in various types of publications. A similar situation prevails in the processing of the area of globalization, its origin and impact, or retail. In 2020, however, the adjective "pandemic" appeared in connection with these areas. We expect that our findings in this regard are not unique, however, they are the result of our original scientific work.

In general, globalization can be defined as an extensive network of economic, cultural, social, and political connections and processes that transcend national borders. On the one hand, it brings opportunities to develop what the company excels at, on the other hand, it highlights its shortcomings. A more open and intense global connection exposes a developed society to security, environmental, climate, health and other similar risks. Nevertheless, no generation before us has had such a good access to food, clothing, technology, healthcare or travel as Europeans have today. A worldwide pandemic poses a cross-border threat that affects not only public health, but also global society. However, preparedness for it has not been and still is not the same in individual countries [1].

While implementing marketing communication tools, the company on the one side informs about itself and its products, explains their benefits and properties, highlights their usefulness, quality, value, advantage, or use, and on the other side listens, receives suggestions and requirements of society and consumers, and responds to them. It may use traditional and non-traditional tools and media in both offline and online environments to influence behaviour. The need for social isolation has contributed to the transfer of almost the entire global population to the online space, which has also caused changes in the marketing communication of companies. Businesses have rediscovered the continuity, immediacy and promptness of the digital environment. Some of the messages were postponed so as not to disappear on the subject, as consumers also put off their decisions. Other communications were reconsidered in terms of creativity, as emotions such as, humour or fear have had a controversial position in society during this period. Others have increased their budget for communication on television and the online environment, or updated social media profiles and strengthened Facebook discussion teams of moderators $[2]$.

\section{Methods}

The main aim of the paper is to discover the topics of the online contents of the retail chain Kaufland Slovakia in communication with customers during an emergency period on its Facebook account, and to compare them with the themes of the articles published during the observed time on the company's Facebook pages in Germany. It should be noted that the German government has not declared a state of emergency in the state. The partial goals are as follows: to identify globalization and marketing communication, to carry out a content analysis of the posted contributions and to compare the set topics, to draw conclusions (whether and how the retail chain reacted to the pandemic situation and measures imposed by the Public Health Authority of the Slovak Republic). University textbooks, proceedings of scientific papers, as well as websites and Facebook pages of Kaufland in Slovakia and in Germany, served to us as information sources. When 
processing resource materials, we applied standard scientific methods: research, description, analysis, deduction, and content analysis.

A content analysis as a research method is a procedure for an objective, systematic and quantitative description of the apparent content of communication or the relationships between the occurrence of individual phenomena. Quantitative description is a purposeful and continuous procedure in the analysis of the text content based on the numerical expression of the frequency of occurrence of analysis elements or the degree of attitude intensity, or another quantification procedure. When performing content analysis, the following quantification procedures are usually applied: determining the frequency of the analysed category, measuring the time allocated to a particular problem, estimating the space devoted to a specific content in a written or printed text, quantification according to a system of categories with equal intervals and absolute zero point, which means full capture of time variable, spatial variable, or other indicators [3]. Through the implemented content analysis, we focused on the examination of the online contents on theFacebookaccounts of Kaufland in Slovakia and Kaufland in Germany in the following quantification procedures: number per calendar month, nature of posts (related or not related to the pandemic). We consider as contributions related to the pandemic, e.g., if focused on health protection, change of opening hours, expressing thanks to front-line employees and as digital items not related to the pandemic the ones that Kaufland would publish even under normal circumstances, for example a new product leaflet, recipes, Mother's day, etc.

Kaufland is a large-format food retailer whose business strategy is based on a unique mix of a wide range of products, mainly branded goods and discount-oriented pricing [4]. The emphasis is put on fresh fruits and vegetables, dairy products, meat, cheese, and fish. The food assortment is complemented by, for instance, household goods, electronics, stationery, toys, textiles, and seasonal goods.

The company opened its first store, called Kaufland, in 1984 on the German market, where is not operates more than 650 stores and, unlike the Slovak market, also the virtual mobile operator K-Classic Mobil [5]. Kaufland entered the Slovak market in 2000, and now it operates 70shops there [6]. In Europe, Kaufland currently operates a total of more than 1, 270 self-service department stores (inGermany, the Czech Republic, Poland, Croatia, Romania, Bulgaria, and Slovakia) [7, 8, 9]. In the German market,it communicates with customers in the online environment via social media Facebook, YouTube, Twitter, Instagram and Pinterest. In Slovakia, it uses social media Facebook, YouTube, Instagram, and Linked to communicate with customers.

\section{Results}

On 16 March 2020, the government of the Slovak Republic responded to the declaration of a global pandemic (epidemic at a global scale) of the disease COVID-19 by the World Health Organization on 11 March 2020, by declaring a state of emergency. As there was an imminent threat to the lives and health of individuals in connection with the outbreak of the pandemic, the government of the Slovak Republic imposed this situation. In times of emergency, the government may restrict fundamental rights and freedoms to the extent and for the time necessary, depending on the seriousness of the threat, and impose a security obligation with reference to the operation of retail activities to guarantee supplying [8]. The state of emergency ended after 90 days on 13 June 2020.

With effect from 16 March 2020 from $6.00 \mathrm{am}$, all retail shops and all retail establishments providing services were closed for a period of 14 days, except forshops offering food, meat, bread and pastry, fruit and vegetables, newspapers and also pharmacies, drugstores, feed stores for animals and operations of online shops [9].However, 
this situation eventually lasted much longer, the first wave of looseningthe restrictions did not come until April 22, 2020.For this time, the Public Health Authority in Slovakia proposed measures in commercial operations that persist even after the emergency: customers can only enter stores with their nose and mouth covered; they are obliged to use hand sanitizer or disposable gloves; one customer per 10 square meters is recommended, with 2 meter intervals between customers; the trader should ensure frequent ventilation of the premises and regular disinfection of the contact surfaces [10,11,12].

In March,during the examined period from 16 March to 31 March 2020, Kaufland in Slovakia posted a total of 24 contributions. Of these, 18 online contents were related to the state of emergency and the pandemic situation in Slovakia. Among the topics, there resonated health protection (hygienic measures, for example, disinfection of shops, handles of shopping carts, installation of plexiglass at the cash registers, use of face masks and disposable gloves), opening hours (special time reserved for seniors, closing of stores on Sundays) and expressing thanks to employees or colleagues from Kaufland, whether working in shops or in logistic centres and administration. [13].The time allocated for shopping of seniors was changed several times, whether from the initiative of traders, negative reactions from the public or decisions of the Slovak government. In the comments of customers on various contributions, but primarily on the posts with the topics of measures, there was a heated discussion about the number of people allowed in stores, noncompliance with distance-keeping, excessive purchases, closing stores on Sundays, or measures taken abroad. Some customers were so hypersensitive that in their comments they manifested theiroutrageon illustrative photos of Kaufland employees without protective masks. In contrast to the topics in Germany, the Kaufland in Slovakia website displayed thanks to front-line health professionals and reports on the provision of donations to hospitals and social service homes. $[14,15,16]$.

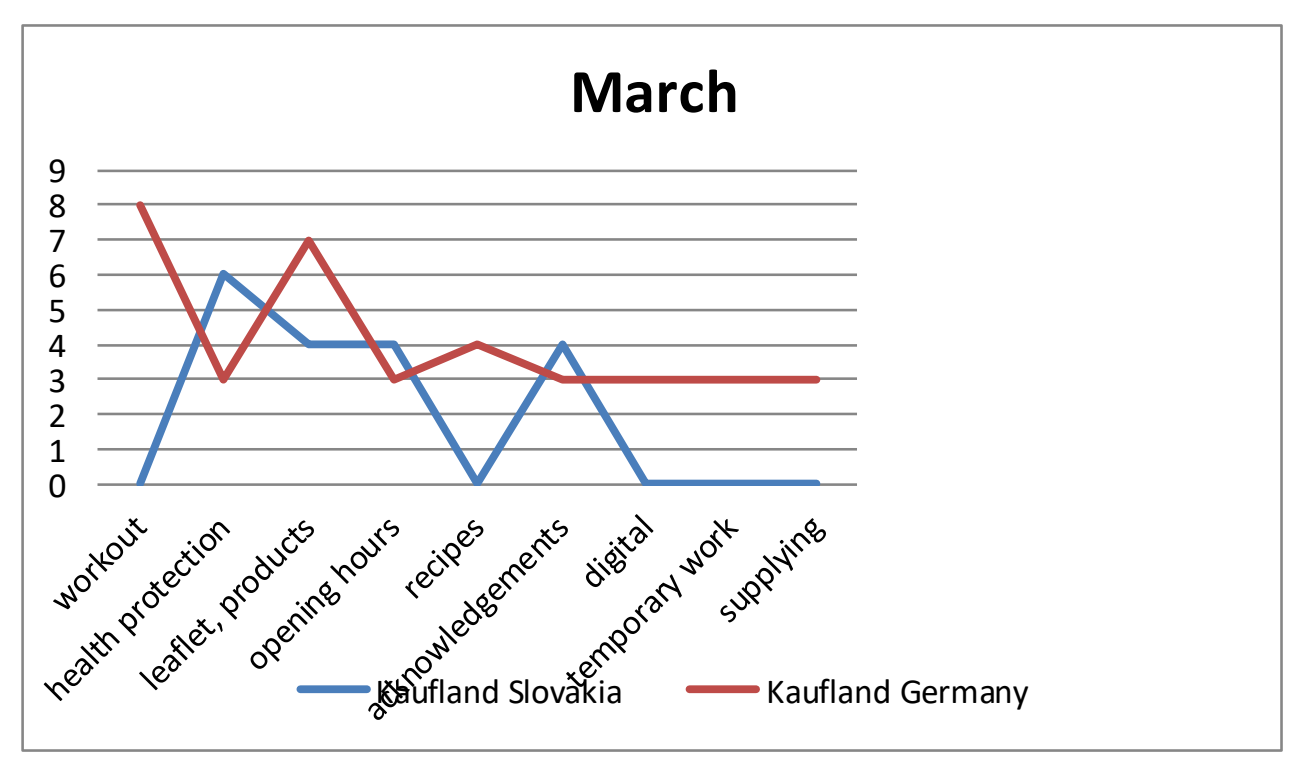

Fig. 1. Comparison of selected topics on Facebook profiles of Kaufland in Slovakia and in Germany.

Source: own processing, 2020

During the investigated period, from 16 March to 31 March 2020, Kaufland Germany issued a total of 43 posts, of which 22 contributions were related to the pandemic situation. There resonated topics, such as, home office workouts, products with a discount on leaflets 
andrecipes. Kaufland Germany paid a balanced attention to announcements related to opening hours (stores remain open as usual), health protection, ensuring that shops are regularly supplied and customers do not have to incline to shopping hysteria, moving customers to the digital environment (websites, mobile applications, social media contain all topical information), or job offers (we are looking for colleagues for temporary work). In comparison with Slovak themes, on the German Facebook page Kaufland for example mediated work offers of agricultural suppliers, called for the return of returnable bottles, which Kaufland's suppliers had lacked, called for accountability and assistance to neighbours, or assured its customers that it was not raising toilet paper prices. It described its employees as heroes.

In April, in the examined period (April 1, 2020 - April 30, 2020), Kaufland Slovakia released a total of 41 posts. Altogether 14 articles were related to the state of emergency and the pandemic situation in Slovakia. The topics included health protection, products with a discount from leaflets and entertainment (online concerts, barbecues, a kiss under the cherry tree). In 2020, Kaufland celebrates 20 years of running on the Slovak market. It responded to this anniversary and the pandemic situation with online live concerts, which were broadcast on four Sunday evenings. Since there was also Easter celebrated in this time, several contributions were devoted to the Easter time, recipes and the call on customers to eliminate the movement around the stores and to make them carry out their purchases, if possible, in only one shop. In the second half of April, Kaufland Slovakia published a post stating that the employees of the Panta Rhei bookstore network were helping out in its stores. During the state of emergency, when the government closed virtually all stores for more than six weeks, except for groceries, it was not uncommon for employers to look for work with others in order to provide income for their employees.

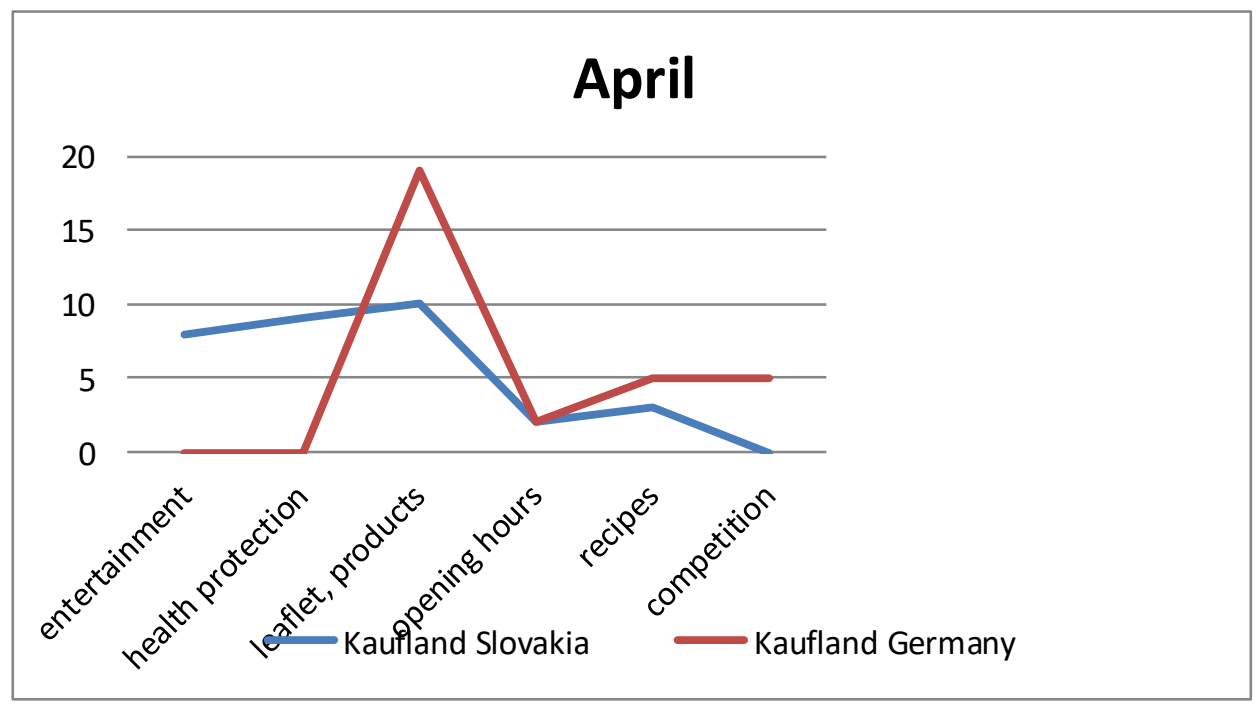

Fig. 2. Comparison of selected topics on Facebook profile of Kaufland Slovakia and Kaufland Germany.

Source: own processing, 2020

In April 2020, Kaufland Germany posted a total of 34 articles, of which only 3 were related to the pandemic situation. It focused its communication on this network mainly on products with a discount on leaflets, recipes (encouragement to cook in the time of social 
isolation) and competitions. After one of two online contents, attention was paid to Easter and the offer of services of the virtual mobile operator K-Classic Mobil. Directly linked to the pandemic situation were posts that reassured customers that stores were open as usual or stimulated them to make early purchases before the Ester period. During April, there were no digital items related to the protection of health, work or acknowledgements for the work of employees on the GermanFacebook page of Kaufland.

In May (May 1, 2020 - May 31, 2020) Kaufland in Slovakia published a total of 39 online contents, where 1 of them was associated to the pandemic situation in Slovakia (Keep social distancing!). Kaufland Germany released 33 posts, none of which responded to the pandemic situation. The Slovak Facebook page was dominated by topics concerning entertainment (online concerts, picnics at home, crossword), discounted products from the product leaflets and a new advertising campaign called "Really Cheap". Kaufland in Germany focused on discounted products in circulars, competitions and support for the virtual mobile operator K-Classic Mobil. Other contributions, whether in Slovakia or in Germany, were dedicated to, for example, Mother's Day, Father's Day or the loyalty programme.

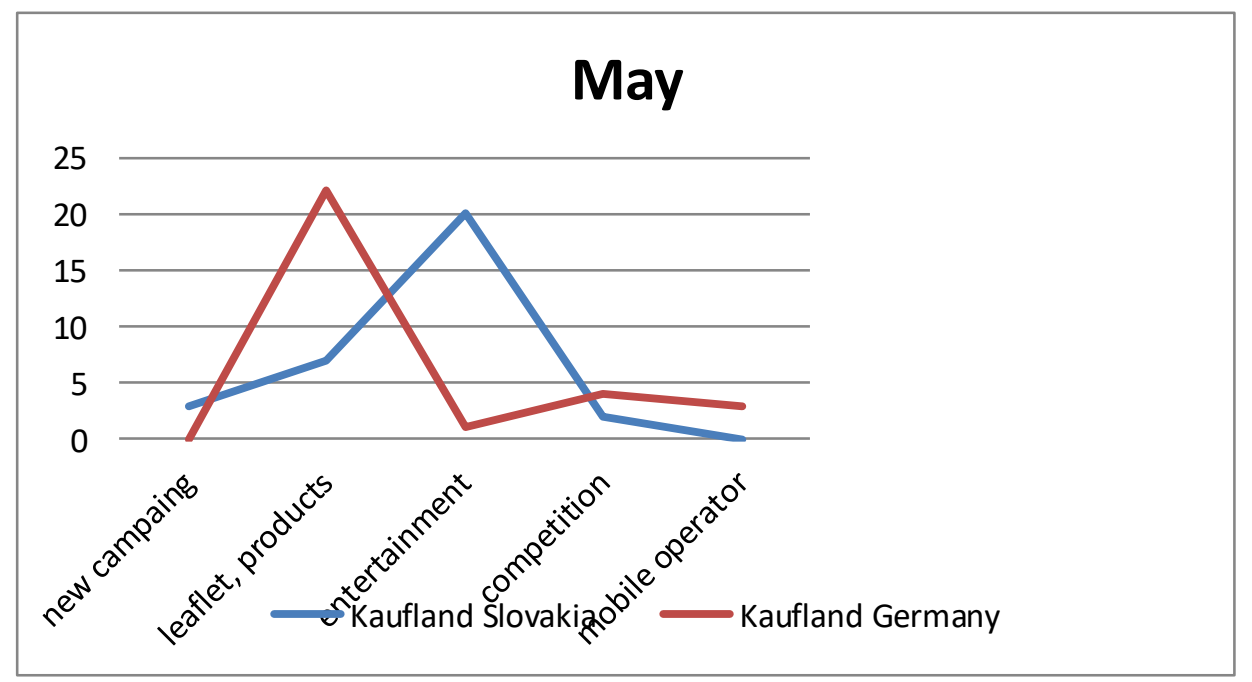

Fig. 3. Comparison of selected topics on the Facebook profiles of Kaufland Slovakia and Kaufland Germany.

Source: own processing, 2020

In June(1 June - 13 June 2020), Kaufland in Slovakia issued a total of 16 posts and Kaufland Germany 11 online contents, while none of them reacted to the pandemic situation. In Slovakia, during the state of emergency,Kaufland published contributions related to the products in the offer of leaflets, expressingthanks to the artists who performed in online concerts for children and adults, for their careers in Kaufland. In this period, German Kaufland released posts concerning products in circulars, competitions and, likewise in Slovakia, digital items related to a possible career in Kaufland.

During the examined period, the number of digital items had a declining tendency. While in March, in the course of nearly two weeks, Kaufland in Slovakia published 18 online contents related to the pandemic, in April it was 14 articles during the month and in May only 1(on keeping social distancing) and in June there was none. On the Facebook 
page of Kaufland in Germany, the declining tendency was even more intense. In March it released 22 posts, in April 3 and no more in May or June.

\section{Discussion}

In the symbolic year of 2020, we were hit by a pandemic, the impact of which on the work-related, social, and personal lives of each of us is unprecedented. The member states of the European Union have reacted differently to this global pandemic, some of them only symbolically (e.g., Germany), others with strict measures (for example, Slovakia). [17, 18, 19]. These different approaches have inspired us to examine how the multinational retail chain Kaufland communicates with its customers in the Slovak market, which has been controlled by strict restrictions, and on the German market, which has approached the protection of public health rather symbolically. By means of a content analysis we found out that probably due to the fact that Germany did not adopt general restrictive rules at the level of the federal government, public health authority or another relevant institution, the Facebook pages of Kaufland Germany did not pay attention to topics, such as, special time set aside for shopping for the elderly, acknowledgements to front-line health professionals, or providing help to hospitals and social home services. On the contrary, similarly to Slovakia, it thanked to colleagues, who were depicted to customers as heroes. Nevertheless, in Slovakia, Kaufland did not assure consumers that stores were supplied on a regular basis and that there was no reason for purchasing hysteria; it did not encourage customers to transfer into digital environment and also did not publish its own work offers (temporary work) or job offers of its suppliers. [20] There were online contents, in which Kaufland in Germany called on its customers to bring returnable bottles, which Kaufland's suppliers had been short of, appealed to customers for responsibility and help towards their neighbours, or reassured their customers that they were not raising toilet paper prices. In April, in connection with the Easter holidays, Kaufland in Slovakia and in Germany appealed to customers to eliminate their movement in the shops and to make their purchases, if possible, only in one store and in advance. At the time of elaborating this paper, we are in the phase of re-adopting strict measures in Slovakia, which should mitigate the health and economic course and the impact of the second wave of the pandemic. Only the development of the coming autumn months will show whether retail traders will have to return to topics posted on their Facebook pages during the spring months of 2020.

\section{References}

1. Chrenek, D. (2020, September 6). Čo nám spôsobuje globalizácia. Available at: $<$ https://ec.europa.eu/slovakia/news/komentar_26052017_sk $>$.

2. Salner, A. (2020, September 4). Marketing na prahu pandémie. Available at: $<$ bastadigital.com/marketing-koronavirus/

3. Kratochvíl, O., Matušíková, I. (2015). Metodika zpracování bakalářské práce I., Kunovice: Evropský polytechnický institut.

4. Stratégie TOP zadávatelov 2018. Špecializovaná príloha mesačníka Stratégie. 03/2019

5. 50 Jahre Kaufland, 50 gute Gründe. Das Jubiläums-Magazin. (2020, August 26). Available $\quad<\quad$ at: $\quad<$ htps://media.kaufland.com/pdf/de/dasjubilaeumsmagazin/catalogs/Jubilaeumsmagazin/pdf/complete.pdf $>$.

6. Kaufland na Slovensku oslavuje 20 rokov. (2020, August 26) Available at: < https://www.tovarapredaj.sk/2020/08/06/kaufland-na-slovensku-oslavuje-20-rokov/> 
7. Kaufland je na Slovensku už 20 rokov. (2020, August 31). Available at: $<$ https://www.retailmagazin.sk/obchodnik/maloobchod/4874-kaufland-je-naslovensku-uz-20-rokov>

8. Ústavný zákon č. 227/2002 Z. z. o bezpečnosti štátu v čase vojny, vojnového stavu, výnimočného stavu a núdzového stavu. (2020, August 31) Available at: https://www.zakonypreludi.sk/zz/2002-227

9. COVID-19: Vláda SR prijala na mimoriadnom zasadnutí d'alšie dôležité opatrenia. (2020, August 31). Available at: $<$ http://www.uvzsr.sk/index.php?option=com_content\&view=article\&id=4098:covid19-vlada-sr-prijala-na-mimoriadnom-zasadnuti-alie-doleiteopatrenia\&catid=250:koronavirus-2019-ncov\&Itemid=153>.

10. Všetky informácie o koronavíruse COVID - 19. (2020, August 31). Available at: $<$ https://www.health.gov.sk/Clanok?Hlavna-sprava-COVID-19>.

11. Costello, J. P., Reczek, R. W. (2020). Providers versus platforms: Marketing communications in the sharing economy. Journal of Marketing, 84(6), 22-38.

12. Borah, A., Banerjee, S., Lin, Y.-T. et al. (2020). Improvised marketing interventions in social media. Journal of Marketing, 84(2), 114-132.

13. Freiwald, N., Nagler, F. (2019). Over-the-Counter market frcitions and yield spread changes. Journal of Finance, 74(6), 3217-3257.

14. August, T., Dao, D., Kim, K. (2019). Market segmentation and software security: Pricing patching rights. Management Science, 65(10), 4575-4597.

15. Rhodes, A., Zhou, J. (2019). Consumer search and retail market structure. Management Science, 65(6), 2607-2623.

16. Kauppinen-Raisanen, H., Gronroos, Ch. (2015). Are service marketing models really used in moder practice? Journal of Service Management, 26(3), 346-371.

17. Olson, D. M., Waguespack, D. M. (2020). Strategic behavior by market intermediaries. Strategic Management Journal, 41(13), 2474-2492.

18. Podhorska, I., Vrbka, J., Lazaroiu, G., Kovacova, M. (2020). Innovations in financial management: Recursive prediction model based on decision trees. Marketing and Management of Innovations, 3, 276-292.

19. Vrbka, J., Nica, E., Podhorska, I. (2019). The application of Kohonen networks for identification of leaders in the trade sector in Czechia. Equilibrium - Quarterly Journal of Economics and Economic Policy, 14(4), 739-761.

20. Podhorska, I., Siekelova, A. (2016). The impact of internally generated goodwill on the financial performance of companies - International comparison. Proceedings of the 16th International Scientific Conference on Globalization and its Socio-Economic Consequences (pp. 1736-1743). Univerzity of Zilina, Slovakia. 